\title{
MENNYIT ÉR A KÖZSZOLGÁLTATÁS? \\ A HULLADÉKKEZELÉSI DÍJSZABÁS ALKOTMÁNYOS PROBLÉMÁI
}

\author{
Szilágyi Emese ${ }^{62}$
}

Az alapvető alkotmányos követelményeknek a közszolgáltatások megszervezése során is érvényesülniük kell. A jogállamiság elvének és az emberi jogoknak az érvényre juttatása mind a fogyasztók, mind a szolgáltatók érdekeinek védelme érdekében elengedhetetlen. A jogállamiság figyelembe vétele ugyanis alkalmas a közszolgáltatások természetében rejlö információs aszimmetria redukálására, illetve a korrupció kiküszöbölésének elösegítésére.

A továbbiakban elsősorban a fogyasztónak, mint alkotmányos jogok alanyának szempontjából közelítem meg a területet, egy konkrét közszolgáltatás, nevezetesen a hulladékkezelés példáján keresztül. A hulladékkezelési közszolgáltatás ugyanis kötelező jellegénél fogva minden háztartást érint; megszervezése és díjszabása azonban számos alkotmányos problémát vet fel a gyakorlatban. A problémakör „állatorvosi lóként” alkalmas lehet a közszolgáltatási díjszabással szemben támasztható alkotmányos elvárások vizsgálatára.

A közszolgáltatások - így a hulladékgazdálkodás - megszervezése során az állam változó szerepfelfogásának jelei érhetők tetten:

- a2011-es Alaptörvény és a hozzá kapcsolódó jogszabályok a korábbitól lényegesen eltérő megközelítésben gondolkodnak a helyi önkormányzatok szerepéről;

- a gazdasági válság egyik hozadékaként a közszolgáltatások szabályozásának elsődleges céljává a díjak növekedésének mérséklése, és a magánbefektetői jövedelem-kivonás korlátozása vált;

- a reformok tekintélyes részéről elmondható, hogy azok a vagyoni átrendeződés és a centralizáció irányába mutatnak, az állam pedig lépésről lépésre kiterjed;

- politikai prioritásként jelent meg a fogyasztói díjak központi meghatározása, azaz a lakossági rezsicsökkentés.

Mindennek jelei jól kitapinthatóak a jogi szabályanyagban is.

Így az új önkormányzati törvény ${ }^{63}$ a hulladékgazdálkodást helyi önkormányzati feladatként definiálja, míg a hulladékokról szóló törvény ${ }^{64}$ a település feladatává teszi a közszolgáltatóval történő szerződéskötést. Fontos változás, hogy az illetékes miniszter kapott felhatalmazást a közszolgáltatási díj megállapítására - ez tehát immár nem az önkormányzat által rendeletben megállapítandó kérdés.

Az Alkotmánybíróság számos esetben úgynevezett jogállami követelményeket állapított meg a hulladékkezelési közszolgáltatás díjszabásával összefüggésben. Egy korai ügyben ${ }^{65} \mathrm{a}$ jogbiztonság elvéből vezette le azt a követelményt, amely szerint a szemétszállítás díjának megállapítása során figyelemmel kell lenni az egyedi életkörülményekre.

\footnotetext{
${ }^{62}$ Szilágyi Emese, tudományos segédmunkatárs, MTA TK JTI

${ }^{63}$ 2011. évi CLXXXIX. törvény Magyarország helyi önkormányzatairól, (Mötv.)

${ }^{64}$ 2012. évi CLXXXV. törvény a hulladékról, (Htv.)

${ }^{65}$ 26/1997. (IV. 25.) AB határozat
} 
A konkrét esetben a probléma az volt, hogy Gárdony képviselötestülete a szemétszállítási szolgáltatásért fizetendő díj megállapítása során azonos díjszabást alkalmazott az eltérő jellegü -nyaraló és állandó használatú - ingatlanok tulajdonosainak vonatkozásában.A testület kimondta, alkotmányos követelmény az, hogy „valamely közszolgáltatás díja megállapításának a jogalkotó az érintett csoportokhoz tartozók körülményeit megfelelö figyelemmel, körültekintéssel és méltányossággal értékelje. ’Valójában a testület ezen érvek mentén akár a hátrányos megkülönböztetés megvalósulását is megállapíthattavolna.

Nem sokkal később erre sor is került egy velenceieset ${ }^{66}$ kapcsán, amelyben a képviselőtestület rendeletalkotása során nem volt arra figyelemmel, hogy az üdülöingatlanok tulajdonosai nem egész évben veszik igénybe a közszolgáltatást. Az éves díjtétel emiatt nem tükrözte a valós használatot és a szemétkibocsátást. A testület ebben az esetben a diszkriminációtilalom sérelmét állapította meg az eltérö élethelyzetekböl fakadó különbségek figyelmen kívül hagyása miatt.

Az Alkotmánybíróság egy klasszikus magánjogi alapelvet, a szolgáltatás-ellenszolgáltatás arányosságának követelményét sértö önkormányzati rendeletet azért semmisített meg, mert azt a jogállamiságból eredő jogbiztonság követelményébe ütközőnek találta. A bírák leszögezték, ${ }^{67}$ hogy ,a tényleges arányosságot az olyan tartalmú rendelkezés valósítja meg, amely a díjat az elszállított szemét mennyisége alapján állapítja meg."

Végül a jogszabályokban sorozatosan ismétlődő problémák arra késztették a testületet, hogy vizsgálja meg, esetlegesen jogalkotói mulasztás eredménye-e az, hogy ilyen széles körben kerül sor alkotmányellenes önkormányzati rendeletalkotásra.

Ennek keretében a testület azegyes helyi közszolgáltatások kötelező igénybevételéről szóló törvény ${ }^{68}$ azon rendelkezéseit vizsgálta meg, amelyek felhatalmazást adtak az önkormányzatoknak a rendeletek megalkotására. A vizsgálat során az $\mathrm{AB}$ megállapította, hogy a felhatalmazó rendelkezés sértette a jogállamiság alapelvét, ugyanis az nem határozta meg a jogalkotási hatáskör terjedelmét és korlátait. Ezekben az esetekben- tekintettel arra, hogy az önkormányzatok többsége a közfeladatot olyan gazdasági szervezet útján látja el, amelyben maga is gazdaságilag érdekelt - az önkormányzatokat a rendeletalkotás során saját gazdasági érdekeik is befolyásolják. A jogállamiság elveinek megfelelő megoldás érdekében a törvényalkotónak kell szabályoznia a közszolgáltatási dijjak megállapításának garanciális szabályait.

Nem találta azonban alkotmányellenesnek azt a megoldást a testület, amikor az ingatlanok tulajdonosainak a használt tárolóedények méretéhez igazodóan kellett a díjat megfizetniük. ${ }^{69}$ Feltétel azonban, hogy az ingatlantulajdonosok több, különböző méretü gyüjtőedény közül választhassanak. Ugyanis a gyüjtőedények közötti választás lehetősége garantálja a díjfizetésre kötelezettek számára, hogy amennyiben ingatlanjukon rendszeresen kevesebb szemét keletkezik, akkor áttérjenek egy kisebb méretü edényre, s csupán az ennek kapcsán felmerülő alacsonyabb költséget fizessék meg.

Az ombudsmani gyakorlat újabb megfontolásokkal egészíti ki az Alkotmánybíróság által felállított követelményrendszert: amennyiben a díjhátralék behajtására nem az arra elöírtak szerint kerül sor, úgy az elvezethet a tisztességes eljáráshoz való jog sérelméhez is.

\footnotetext{
${ }^{66} 54 / 1998$. (XI. 27.) AB határozat

${ }^{67} 48 / 2000$. (XII. 18.) AB határozat

${ }^{68}$ 1995. évi XLII. törvény az egyes helyi közszolgáltatások kötelező igénybevételéről, (Kötv.)

${ }^{69} 506 / \mathrm{B} / 2001$. AB határozat
} 
A biztos a közszolgáltató által kiküldött fizetési felszólításokkal összefüggésben állapította meg, hogy a díjhátralék, a késedelmi kamat és a behajtás költségei adók módjára behajtandó köztartozásnak minősülnek. ${ }^{70}$ Ezek behajtását a közszolgáltató a település jegyzőjénél kezdeményezheti. Az ombudsman rámutatott, hogy „amikor a közszolgáltató a törvényi feltételek figyelmen kívül hagyásával jár el a díjhátralék beszedése során, a jogállamiság elvének, az abból fakadó jogbiztonság követelményének, a tisztességes eljáráshoz, valamint a jogorvoslathoz való jognak a sérelmét valósítja meg."

Az ombudsmani gyakorlatból szembetűnő, hogy számos esetben közel azonos „típushibák” voltak megállapíthatók:

- a közszolgáltatás szüneteltetésének szabályozására nem, vagy nem megfelelően került sor;

- a gyüjtőedények mérete nem differenciált, ezért nem teljesül az egyenértéküség és a szolgáltatás-ellenszolgáltatás arányosságának elve;

- az elmaradt közszolgáltatási díjak behajtása során a szolgáltató jár el az önkormányzat adóhatósága helyett, amely önkényes gyakorlat a tisztességes eljáráshoz való jog sérelméhez vezet;

- tényleges ellenszolgáltatás nélkül került sor díjkövetelésre.

Bár a jogszabályi keretek a közelmúltban szignifikánsan megváltoztak, a gyakorlat azt mutatja, hogy a közszolgáltatási díjszabással kapcsolatos problémák szinte konstansnak tekinthetők. Az ombudsmani jelentésekből kitünik, annak ellenére, hogy az önkormányzatok a 2013. január 1-jét követö időszakra hatályosan nem alkothattak és nem is tarthattak hatályban a közszolgáltatási díjat megállapító rendeleteket,több települési önkormányzat közszolgáltatási díjat állapított meg.

A Kúria is több esetben rámutatott, hogy számos önkormányzat jogalkotási kötelezettségének nem, vagy nem megfelelően tett eleget. A Htv. 88. § (4) bek. értelmében ugyanis az önkormányzatok rendeletalkotási kötelezettsége bár korlátozottan, de fennmaradt: helyi rendeletben kell szabályozni ugyanis a hulladékgazdálkodási közszolgáltatás ellátásának és igénybevételének szabályait, továbbá a köztisztasági rendelkezéseket, valamint a díjalkalmazási és díjfizetési feltételeket.

Azonban, a kúriai gyakorlatból kiolvasható, hogy több önkormányzat elmulasztott eleget tenni a jogalkotási kötelezettségének. A bírói fórum arra is felhívta a figyelmet, hogy a felhatalmazás terjedelme korlátozott: bár a jogalkotási kötelezettség fennáll, a „teljesítésekor figyelemmel kell lennie a hulladékgazdálkodási közszolgáltatási díj megállapításáért felelős miniszter hulladékgazdálkodási közszolgáltatás díjait, díjalkalmazási feltételeket megállapító, valamint a díjmegfizetés rendje körében megalkotott rendeletében foglaltakra."

Más esetekbena Kúria is azt állapította meg, hogy a felhatalmazás címzettjének megváltozása ellenére a települési képviselő testület rendeletben állapította meg a hulladékkezelési közszolgáltatás díját. ${ }^{72} \mathrm{Az}$ ilyen, törvénysértő önkormányzati rendeleteket a Kúria megsemmisíti.

Úgy tünik, a hulladékszállítási díjszabással kapcsolatos alapvető problémák immár két és fél évtizede változatlanok: a díjszabás során figyelmen kívül maradnak az eltérő élethelyzetben lévők szempontjai, amely az egyenlö bánásmód sérelmével jár. Vagy jogszabályi hiányosságok, vagy közszolgáltatói gyakorlat eredményeként aránytalanságok jelentkeznek az

\footnotetext{
${ }^{70} \mathrm{https} / / /$ www.ajbh.hu/kozlemenyek-archiv/-/content/10180/15/ismet-a-kukasedenymereterol;jsessionid=650410D229F56AFD7BE68AC2EA7E613A (2015. 09.25.)

${ }^{71}$ Köm.5006/2014/3.

${ }^{72}$ Köf.5015/2014/3.
} 


elvégzett közszolgáltatás és a megfizetendő díj tekintetében, amely a

jogbiztonságotveszélyezteti. A díjhátralékok behajtása során a közszolgáltatók önkényesen járnak el, amely a tisztességes eljáráshoz való jog sérelméhez vezet.

$\mathrm{Az}$ ombudsmani és kúriai esetjog vizsgálata rávilágít arra is, hogy a jogszabályok módosulása, illetve a hatáskörök megosztása az illetékes miniszter és a települési önkormányzatok között újabb bizonytalanságokat idéz elö. Ezt példázzák azok az esetek, ahol az önkormányzatok elmulasztanak eleget tenni jogalkotási kötelezettségüknek, vagy felhatalmazó rendelkezések hiányában is rendeletet alkotnak. 